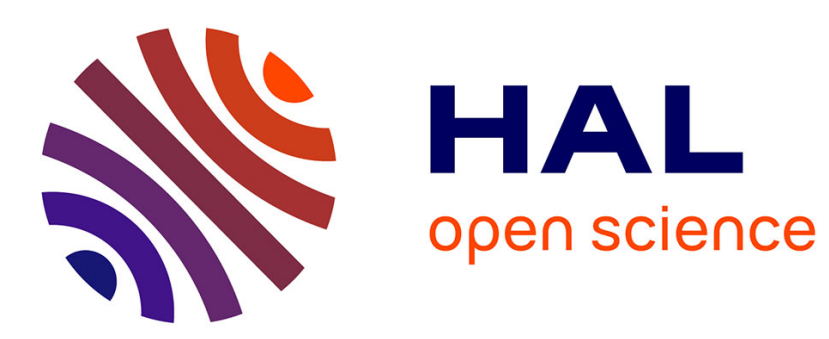

\title{
Estrogen and the cystic fibrosis gender gap
}

Vinciane Saint-Criq, Brian J. Harvey

\section{To cite this version:}

Vinciane Saint-Criq, Brian J. Harvey. Estrogen and the cystic fibrosis gender gap. Steroids, 2014, 81, pp.4-8. 10.1016/j.steroids.2013.11.023 . hal-02394662

\section{HAL Id: hal-02394662 \\ https://hal.science/hal-02394662}

Submitted on 4 Dec 2019

HAL is a multi-disciplinary open access archive for the deposit and dissemination of scientific research documents, whether they are published or not. The documents may come from teaching and research institutions in France or abroad, or from public or private research centers.
L'archive ouverte pluridisciplinaire HAL, est destinée au dépôt et à la diffusion de documents scientifiques de niveau recherche, publiés ou non, émanant des établissements d'enseignement et de recherche français ou étrangers, des laboratoires publics ou privés. 
Review

\title{
Estrogen and the cystic fibrosis gender gap
}

\author{
Vinciane Saint-Criq, Brian J. Harvey* \\ Department of Molecular Medicine, Royal College of Surgeons in Ireland, RCSI-ERC, Beaumont Hospital, Dublin 9, Ireland
}

\section{A R T I C L E I N F O}

\section{Article history:}

Available online 14 December 2013

\section{Keywords:}

Estrogen

Cystic fibrosis

CF gender gap

\begin{abstract}
A B S T R A C T
Cystic fibrosis (CF) is the most frequent inherited disease in Caucasian populations and is due to a defect in the expression or activity of a chloride channel encoded by the cystic fibrosis transmembrane conductance regulator (CFTR) gene. Mutations in this gene affect organs with exocrine functions and the main cause of morbidity and mortality for CF patients is the lung pathology in which the defect in CFTR decreases chloride secretion, lowering the airway surface liquid height and increasing mucus viscosity. The compromised ASL dynamics leads to a favorable environment for bacterial proliferation and sustained inflammation resulting in epithelial lung tissue injury, fibrosis and remodeling. In CF, there exist a difference in lung pathology between men and women that is termed the "CF gender gap". Recent studies have shown the prominent role of the most potent form of estrogen, $17 \beta$-estradiol in exacerbating lung function in CF females and here, we review the role of this hormone in the CF gender dichotomy.
\end{abstract}

() 2013 Elsevier Inc. All rights reserved.

\section{Contents}

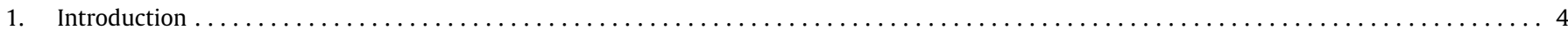

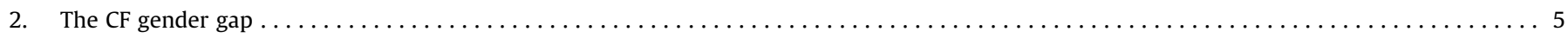

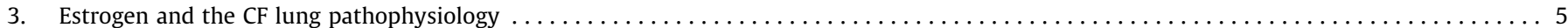

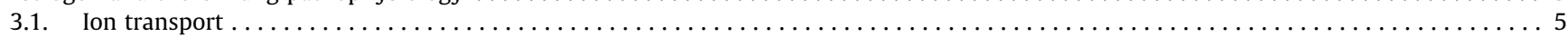

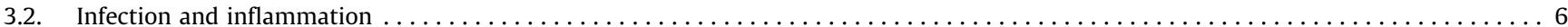

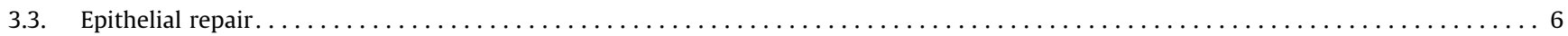

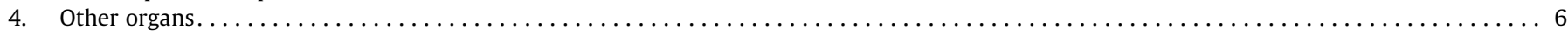

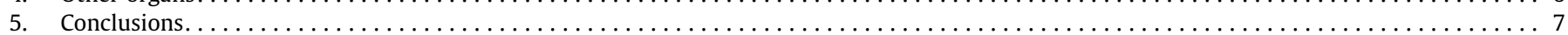

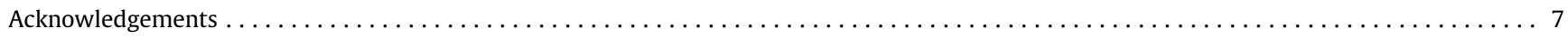

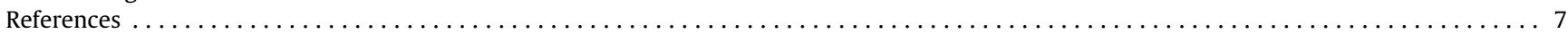

\section{Introduction}

Cystic fibrosis (CF) is the most frequent inherited disease in Caucasian populations. CF is caused by a mutation in the cystic fibrosis transmembrane conductance regulator gene (cftr) leading to a defect in ion transport across the epithelia of organs with exocrine function such as the lungs, pancreas, gastrointestinal and reproductive tract. The CFTR protein is a chloride channel and its most frequent mutation, resulting from a deletion of a phenylalanine in position 508 (F508del), creates a mis-folded protein that remains in the endoplasmic reticulum and is degraded by the cell. The foremost cause of morbidity and mortality in CF is the lung

\footnotetext{
* Corresponding author. Address: Department of Molecular Medicine, Education and Research Centre, Royal College of Surgeons in Ireland, Beaumont Hospital, Dublin 9, Ireland. Tel.: +353 18093817.

E-mail address: bjpharvey@rcsi.ie (B.J. Harvey).
}

pathophysiology [1]. The defect in $\mathrm{Cl}^{-}$secretion generates abnormally thick, dehydrated and viscous mucus at the surface of the airways preventing ciliary beat and providing a favorable environment for bacterial proliferation [2,3]. Staphylococcus aureus, Haemophilus influenzae, and Pseudomonas aeruginosa are the main bacteria found in CF patients lungs and there appearance is correlated with increasing exacerbations and decreased lung function [4]. The host response to this sustained infection implies a maintained inflammatory status characterized by increased levels of cytokines (InterLeukin (IL)-8, IL-6, TNF- $\alpha$, IL-1 $\beta$ ) and infiltration of the airways by neutrophils [5,6]. The vicious cycle of infectious and inflammatory processes leads to structural changes and epithelial tissue damage [7] that fails to repair in these conditions [8,9]. In the intestines, the lack of CFTR causes meconium ileus in CF newborns and distal intestinal obstruction syndrome may appear in CF adults [10]. In the pancreas, the thickened secretions 
block the excretion of digestive enzymes that help during digestion resulting in damaged pancreatic ducts and pancreatitis [11]. As the therapies have evolved, life expectancy for CF patients has significantly increased and new CF related pathologies have appeared. Indeed, mutations in CFTR also disrupt the endocrine function of the pancreas, destructing the islets of Langerhans and leading to a specific type of diabetes called the cystic fibrosis-related diabetes (CFRD) that shares specificities from both type I and type II diabetes [12]. The reproductive tract is also affected as more than $95 \%$ of male CF patients are infertile due to an absence of the vas deferens [13] and female CF patients show a decreased fertility due to a thickened cervical mucus and/or malnutrition [14].

Although life expectancy has greatly increased over the last decade, there exist a difference in survival as well as in the pathophysiology of $\mathrm{CF}$ between male and female patients. This difference is termed the "CF gender gap" and increasing evidence point towards estrogen as the prominent cause of this dichotomy [15-17].

\section{The CF gender gap}

Epidemiological differences between male and female $\mathrm{CF}$ patients have been observed and reported in the early literature. In a study from 1996, Corey and Farewell analyzed the data from 3795 CF patients from the Canadian Cystic Fibrosis Foundation from 1970 to 1989 [18]. They evaluated the frequency, prevalence and mortality of CF in the Canadian population. Over the 20 year period, they found an 8 years difference in the median survival age between males and females. They also reported that until at least 30 years of age, the difference in survival between sexes increased. According to their study, this sex difference could not be explained by poorer pulmonary function in females but was associated with poorer weight maintenance although the analysis of these data using a 3-variable model with sex, weight, and $\mathrm{FEV}_{1}$, suggested a more complex relation between these parameters and mortality [18]. Worse survival for females was confirmed in a study from the UK in which the survival and mortality were evaluated in CF patients between 1947 and 2003. Their data show that in their cohort, in 2003, the median age of survival was around 32 years old for females when it was around 42 for males [19]. Other studies from the US [16,20] and Italy [21], also reinforced the existence of a CF gender gap and although the difference in median age survival between CF men and women may differ from one study to another or one country to another, there is now a strong accumulation of evidence for a lower survival of $C F$ females compared to males and an association of female gender with worse prognosis.

The absence of a molecular mechanism of the precise cause of the CF gender gap as well as the decrease in difference between males and females survival has recently provoked the re-evaluation of the existence of a female-gender disadvantage. Indeed, Verma and colleagues, in a study from 2005 , performed a retrospective analysis of annual assessment data for the years 1993 and 2002 as well as two longitudinal studies each lasting 5 years [22]. Their results showed no difference in survival between $\mathrm{CF}$ females and males and even reported a better overall $\mathrm{FEV}_{1}$ percent predicted in females than in males. Another recent study from Italy could not find any gender difference in their cohort of more than 2000 $\mathrm{CF}$ patients although, due to $\mathrm{CF}$, female patients lose their survival advantage that is found in the general population [23]. Both studies included survival rates of young CF patients (children and adolescents) and this might explain why the gender difference, likely to occur after puberty, could not be observed.

In order to evaluate the existence of a CF gender gap in view of the new types of treatments and the increased overall median age survival, Kulich et al. used the Cox proportional hazards model to study a cohort of more than 30,000 CF patients retrospectively and showed that females had poorer prognosis than males [24]. More recently Jackson et al. reported the same type of results and showed and improved overall CF survival in Ireland as well as the existence of a CF gender gap in this cohort of $659 \mathrm{CF}$ patients [25]. It is therefore clear that female gender is associated with worse prognosis and this is true in different cohorts and countries.

Recent literature has focused on determining the potential crucial role of estrogen in the establishment of the CF gender gap.

\section{Estrogen and the CF lung pathophysiology}

Lung pathophysiology is the foremost cause of morbidity and mortality in CF. Exacerbations in lung function in CF are characterized by a airway mucus plugging, a sustained bacterial infection and inflammation vicious cycle leading to injured epithelium and tissue destruction. In the following section we review the effects of the estrogen $17 \beta$-estradiol (E2) on airway pathophysiology, and the mechanisms of action involved in these processes. The pulmonary epithelium is a target for steroid hormones and their effects on lung function, inflammatory and immune mechanisms have been recently studied in-depth and a review is timely.

\subsection{Ion transport}

$\mathrm{CF}$ is caused by a defective $\mathrm{Cl}^{-}$channel resulting in imbalanced ion transport across the epithelia lining the airways. The airway epithelium is covered by an aqueous film termed the airway surface liquid (ASL) composed of the periciliary layer and the mucus layer and is the main barrier against the entry of pathogens into the lungs. In non-CF subjects, the ASL height is tightly regulated in order to maintain an approximately $7 \mu \mathrm{m}$ height to allow cilia beating and removal of trapped particles and pathogens in the mucus layer [2]. Chloride secretion, $\mathrm{Na}^{+}$absorption and $\mathrm{K}^{+}$recycling are mainly responsible for the transport of water and therefore the hydration of the ASL. As in other epithelia, $\mathrm{Na}^{+}$is transported from the apical surface to the blood via apical membrane $\mathrm{Na}^{+}$channel and the basolateral $\mathrm{Na}^{+} / \mathrm{K}^{+}$-ATPase. The recycling of $\mathrm{K}^{+}$through potassium-selective ion channels across the basolateral membrane provides the driving force for $\mathrm{Cl}^{-}$secretion across the apical membrane. $\mathrm{Cl}^{-}$is secreted from the basolateral to the apical side through the $\mathrm{Na}^{+} / \mathrm{K}^{+} / 2 \mathrm{Cl}^{-}$co-transporter and apical $\mathrm{Cl}^{-}$channels such as the cystic fibrosis transmembrane conductance regulator (CFTR) or $\mathrm{Ca}^{2+}$-activated $\mathrm{Cl}^{-}$channels (CaCC). It has been shown in $\mathrm{CF}$ that the ASL height is decreased compared to non-CF epithelium and our group and others have shown that E2 causes a further decrease in ASL height in CF epithelia. Until recently, little was known about the effect of female hormones on airway epithelial ion transport. It has been shown that estrogen may modulate ion transport in airway epithelial cells and that this can have beneficial or deleterious effects depending on the tissue compartment and on the physiology/pathophysiology state of the airways [26-28]. Thus it would appear that estrogen affects $\mathrm{Na}^{+}$reabsorption and fluid clearance in the lung. Indeed, Sweezey et al. in 1998 showed an increase in ENaC activity and mRNA copies in isolated alveolar type II epithelial cells due to E2 [29]. A later study by Laube et al. described that a cocktail of estrogen and progesterone increased basal short-circuit current as well as amiloride- and ouabainsensitive currents in alveolar epithelial cells. This study also showed, that these hormones increased the mRNA expression levels of $\alpha$ - and $\beta$-ENaC subunits and the $\mathrm{Na}^{+} / \mathrm{K}^{+}$-ATPase $\beta 1$ subunit [27]. These results further indicate a regulatory role for female sex hormones on $\mathrm{Na}^{+}$absorption in airway epithelium with a physiological consequence for alveolar airway fluid clearance. A recent study has shown that the amiloride-insensitive nasal potential 
difference (NPD) increased in CF female patients during the luteal phase (high estrogen + progesterone concentration) of the menstrual cycle when compared to the follicular phase [30], probably due to an altered transepithelial $\mathrm{Na}^{+}$absorption. Other groups have studied the effect of estrogen on $\mathrm{Cl}^{-}$transport in $\mathrm{CF}$ female patients and in CF bronchial epithelial cell lines. Fanelli et al. showed an increase of $\mathrm{Cl}^{-}$efflux in the CF bronchial epithelial cell line CFBE41oafter $17 \beta$-estradiol treatment. This effect was due to an increase in F508del-CFTR in the apical membrane through the up-regulation of NHERF1 [31], although this does not correlate with different studies supporting the deleterious effect of E2 in CF bronchial epithelia. In 2008, Tarran's group showed a decrease in UTP induced nasal potential difference during high estrogen blood levels in $\mathrm{CF}$ and non-CF female patients. From this observation, they studied the effect of estrogen on nucleotide-mediated ASL regulation and found that E2 decreased $\mathrm{Ca}^{2+}$ signalling and impaired ASL volume homeostasis through the estrogen receptor ER $\alpha$ [32]. This group had also shown recently that E2 inhibits Store-Operated Calcium Entry (SOCE) through ER $\alpha$, the inhibition of STIM oligomerization and activation of Orai1. This prevents the activation of $\mathrm{Ca}^{2+}$ activated $\mathrm{Cl}^{-}$channels and could therefore further decrease ASL height in $\mathrm{CF}$ female patients [33]. Results from our group, published very recently, show that, in CF bronchial epithelial cell lines as well as primary bronchial cells from CF female patients, E2 decreased significantly ASL height and targeting specifically ENaC and the $\mathrm{Na}^{+}$/ $\mathrm{K}^{+}$ATPase through the activation of the PKC $\delta$ in order to increase $\mathrm{Na}^{+}$and obligatory water absorption [34]. The rapid action of E2 on ASL height was shown to involve the activation of an extra-nuclear ER $\alpha$ with similar responses generated by a non-nuclear estrogen dendrimer conjugate [34], a compound allowing the discrimination between genomic and non-genomic effects of E2 [35].

\subsection{Infection and inflammation}

A decisive predictive marker of the decline of pulmonary function in CF patients is the colonisation of the airways by $P$. aeruginosa (Psa), especially the mucoid form of this bacterium. Psa is a gram-negative, monoflagellated bacterium that can switch from a non-mucoid to a mucoid form through a large production of a polysaccharide, the alginate, which protects the biofilm bacteria against the host's innate immune system. Early cohort studies showed an association between female gender and an earlier median age of chronic infection with mucoid Psa [15]. More than 15 years later, these results were reproduced in a study from Pittman et al. in which they showed that there exist a stronger association between the age of persistent Psa infection (as well as the age at first Psa infection) and the severity of lung disease in females than in males. These results have led some groups to study the potential effect of E2 on the host innate immune system when challenge with Psa.

Estrogen has been shown to modulate the innate immune response in macrophages [36]. In a very interesting study from 2010, CF mice, when injected with estrogen and then infected with $P$. aeruginosa, showed an increase number of white blood cells and PMN (polymorpho nuclear neutrophils) in the whole lung and in the broncho-alveolar lavage. E2 exposure in the lung of CF mice increased the inflammatory infiltrate, mucin and the mRNA levels of Toll Like Receptor 2, InterLeukin (IL)-23 and IL-17A [37]. Secretory leucoprotease inhibitor (SLPI) is an anti-protease that has shown anti-inflammatory effects and is able to competitively bind to the nuclear factor (NF)- $\kappa B$ DNA binding sites thus inhibiting this transcription factor activation [38]. The study by Chotirmall et al. (2010), showed that E2 up-regulates SLPI to inhibit NF- $\kappa B$ thus reducing IL-8 production and compromising a protective inflammatory processes leading to a rise in Psa infection and colonization [39].

A more recent study from Chotirmall et al. reported that estrogen induced the production of alginate from the PAO1 Pa strain and clinical isolates from CF patients as well as the transformation of Psa from a non-mucoid to a mucoid form. The underlying molecular mechanism was shown to involve the spontaneous mutation in mucA caused by the inhibition of catalase activity and increased production of hydrogen peroxide by the Psa bacterium. In this paper, the authors also report a very interesting correlation between the concentration of plasma E2 from CF females and the number of lung exacerbations. This correlation was not found in women using oral contraceptives and these women showed lower rates of lung function exacerbations. Of clinical significance, the study also showed that mucoid bacteria were predominantly isolated during high-estradiol phases of the menstrual cycle in CF females [40].

Although these studies already depict the deleterious effects of estrogen on the infectious and inflammatory processes in $\mathrm{CF}$ female lungs, there exist more actors of the innate immunity and the effect of the female hormone on these remain unknown. Indeed, in non-CF healthy subjects, the eradication of bacteria such as Psa involves the recognition of Pathogen Associated Molecular Patterns (PAMPs) by the Pattern Recognition Receptors (PRRs). In this innate immune system, the Toll-Like Receptors (TLRs) play an important role in initiating the immune response by recognizing, in the case of Psa, the LPS or the flagellin [41]. Moreover, the balance between proteases and anti-proteases also plays an important role in the protection of the airways. Indeed, bacteria are able to secrete virulence factors such as proteases in order to enhance its survival. On the other hand, airway cells produce and secrete anti-proteases such as $\alpha$-1-antitrypsin, SLPI or elafin in order to counter-balance the production of proteases by the pathogens or the neutrophils and regulate their activity. Finally, epithelial cells produce anti-microbial peptides that help to protect the lungs against infection. These peptides, such as $\beta$-defensins, have been reported to be decreased in bronchoalveolar lavages from $\mathrm{CF}$ patients [42]. These effects of estrogen on different aspects of the lung immune system have not been reported so far and further analysis is needed in order to evaluate their potential contribution to the CF gender dichotomy.

\subsection{Epithelial repair}

Estrogen differently modulates cell proliferation and migration depending on the tissue and the environment according to its beneficial or deleterious effects in cancers $[13,43,44]$. In non-cancer cells, E2 has been shown to regulate these processes and although, to our knowledge, the effect of E2 on CF pulmonary epithelial repair has yet to be evaluated, recent studies in other tissues suggest that it could negatively regulate wound healing. A study from Wang et al. showed that E2 delayed corneal epithelial wound repair and that this process is mediated by ER $\alpha$ and ER $\beta$. This process was correlated with a down-regulation of lipoxin A4 (LXA4) expression and the E2-induced decrease in wound healing rate was reversed by LXA4 [45]. Moreover, Buchanan et al. recently showed that LXA4 activated $\mathrm{K}^{+}$currents lead to an increased capacity for epithelial repair in CF bronchial cell cultures [46]. Taken into account the inhibitory effect of E2 on $\mathrm{K}^{+}$channels shown by our group [34], the overall picture strongly suggests that E2 could negatively regulate epithelial wound healing of CF bronchial epithelia.

\section{Other organs}

As survival increases, $\mathrm{CF}$ patients are more at risk to develop non-pulmonary CF-related diseases such as CF bone disease (CFBD) 


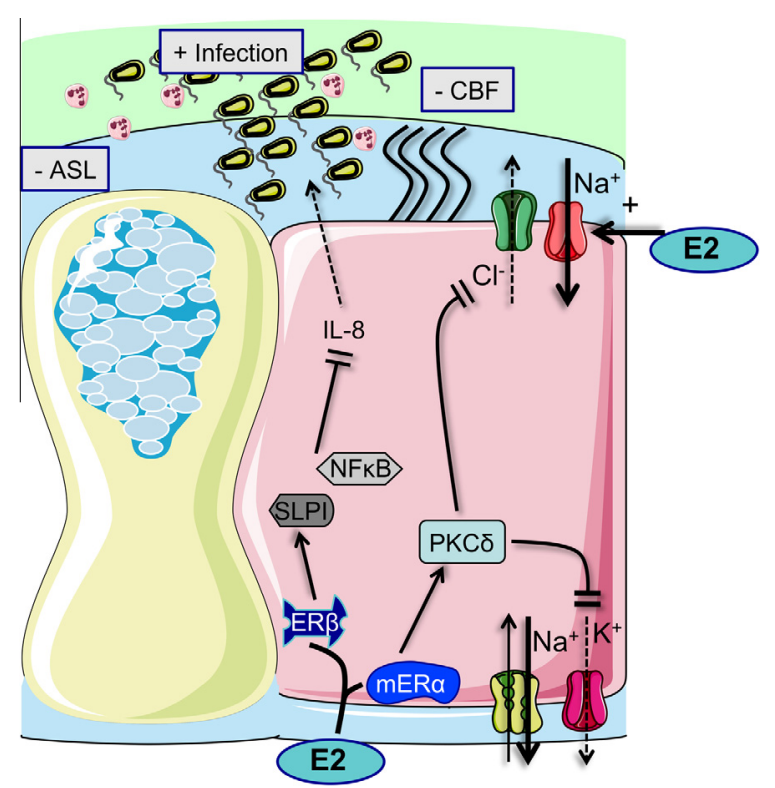

Fig. 1. Molecular mechanisms of action of $17 \beta$-estradiol (E2) in CF lung involving: (1) E2-membraneERa induced PKC $\delta$ signal transduction to cause a compromised airway liquid dynamics (ASL - airway liquid height, CBF - ciliary beat frequency) and ion transport dysfunction (inhibited $\mathrm{Cl}^{-}$channels, activated $\mathrm{Na}^{+}$channels); E2ERb induced stimulation of secretory leucoprotease inhibitor leading to inhibition of NF- $\kappa \mathrm{B}$ activation and IL-8 production/secretion leading to a compromised innate immunity. Estrogen also enhances Pseudomonas aeruginosa mucoidy and biofilm production.

and $\mathrm{CF}$ related diabetes (CFRD). With improved health and increased survival, more $\mathrm{CF}$ women have the desire to become pregnant but they face many more complications than non-CF pregnant women.

Estrogen has been shown to regulate multiple physiological and pathophysiological processes in many organs. Although, the effect of E2 in organs affected by CF, other than the lungs, has been poorly evaluated, there exist some interesting studies that can help in understanding the cellular response to E2. In 2008, Fahey et al. showed that in non-CF uterine epithelial cells, E2 blocked LPS-induced cytokine secretion and induced SLPI secretion, as well as increasing the production of antimicrobial peptides [47]. Taken together with the study from Chotirmall et al. [39], it may be envisaged that E2 could decrease uterine inflammation in CF females which may in turn favor infection and modulate fertility.

It is widely known that, in the general population, the drop of estrogen after menopause increases bone loss in women. In 2009, Pashuck et al. showed, in a CF murine model, that female CF mice had reduced mineralizing surface and bone formation rates than their male counterparts [48].

Finally, $20 \%$ of CF adolescents and $40-50 \%$ of adult CF patients develop CFRD [49]. A diagnosis of CFRD has been reported to be associated with a worsened nutritional status, more severe lung disease, and greater mortality [50]. Moreover, it has been shown that diabetes is linked with a decreased survival in CF females [51] although the sex difference between male and female mortality rates appear to narrow considerably [49].

\section{Conclusions}

There is now strong evidence from epidemiology, molecular endocrinology and physiological studies that raised plasma levels of estrogen can exacerbate lung pathophysiology and function in $\mathrm{CF}$ females. The molecular basis for the $\mathrm{CF}$ gender gap involves a compromised innate immune response via E2-ER $\beta$ receptor signal transduction to inhibit NF- $\kappa \mathrm{B}$ transcription factor activation and IL-8 production combined with a reduced airway surface liquid dynamics arising from E2-ER $\alpha$ receptor signal transduction to activate $\mathrm{ENaC} \mathrm{Na}{ }^{+}$absorption and dehydration of the periciliary layer (Fig. 1). In addition, estrogen acts directly on $P$. aeruginosa conversion to mucoid form and biofilm production completing a vicious cycle of compromised mucocilairy clearance, infection and inflammation.

\section{Acknowledgements}

The authors' work was supported by Grants from the Higher Education Authority of Ireland PRTLI4 NBIP (B.J.H.), EU Marie Curie CEMP (V.S.-C.), and European Science Foundation CF COST BM1003 (BJH).

\section{References}

[1] Davis PB, Drumm M, Konstan MW. Cystic fibrosis. Am J Respir Crit Care Med $1996 ; 154: 1229-56$

[2] Matsui H, Grubb BR, Tarran R, Randell SH, Gatzy JT, Davis CW, et al. Evidence for periciliary liquid layer depletion, not abnormal ion composition, in the pathogenesis of cystic fibrosis airways disease. Cell 1998;95:1005-15.

[3] Wine JJ. The genesis of cystic fibrosis lung disease. J Clin Invest 1999;103:309-12.

[4] Tümmler B, Kiewitz C. Cystic fibrosis: an inherited susceptibility to bacterial respiratory infections. Mol Med Today 1999;5:351-8.

[5] Sommerhoff CP, Nadel JA, Basbaum CB, Caughey GH. Neutrophil elastase and cathepsin $\mathrm{G}$ stimulate secretion from cultured bovine airway gland serous cells. J Clin Invest 1990;85:682-9.

[6] Nakamura H, Yoshimura K, McElvaney NG, Crystal RG. Neutrophil elastase in respiratory epithelial lining fluid of individuals with cystic fibrosis induces interleukin-8 gene expression in a human bronchial epithelial cell line. J Clin Invest 1992;89:1478-84.

[7] Bruce MC, Poncz L, Klinger JD, Stern RC, Tomashefski JF, Dearborn DG. Biochemical and pathologic evidence for proteolytic destruction of lung connective tissue in cystic fibrosis. Am Rev Respir Dis 1985;132:529-35.

[8] Trinh NTN, Bardou O, Privé A, Maillé E, Adam D, Lingée S, et al. Improvement of defective cystic fibrosis airway epithelial wound repair after CFTR rescue. Eur Respir J 2012:40:1390-400.

[9] Hajj R, Lesimple P, Nawrocki-Raby B, Birembaut P, Puchelle E, Coraux C. Human airway surface epithelial regeneration is delayed and abnormal in cystic fibrosis. J Pathol 2007;211:340-50.

[10] Littlewood JM. Cystic fibrosis: gastrointestinal complications. Br Med Bull 1992;48:847-59.

[11] Wilschanski M, Novak I. The cystic fibrosis of exocrine pancreas. Cold Spring Harb Perspect Med 2013;3:a009746.

[12] Kelly A, Moran A. Update on cystic fibrosis-related diabetes. J Cyst Fibros 2013;12:318-31.

[13] Yu J, Chen Z, Ni Y, Li Z. CFTR mutations in men with congenital bilateral absence of the vas deferens (CBAVD): a systemic review and meta-analysis. Hum Reprod 2012;27:25-35.

[14] Lyon A, Bilton D. Fertility issues in cystic fibrosis. Paediatr Respir Rev 2002:3:236-40.

[15] Demko CA, Byard PJ, Davis PB. Gender differences in cystic fibrosis: Pseudomonas aeruginosa infection. J Clin Epidemiol 1995;48:1041-9.

[16] Rosenfeld M, Davis R, FitzSimmons S, Pepe M, Ramsey B. Gender gap in cystic fibrosis mortality. Am J Epidemiol 1997;145:794-803.

[17] Olesen HV, Pressler T, Hjelte L, Mared L, Lindblad A, Knudsen PK, et al. Gender differences in the Scandinavian cystic fibrosis population. Pediatr Pulmonol 2010:45:959-65.

[18] Corey M, Farewell V. Determinants of mortality from cystic fibrosis in Canada, 1970-1989. Am J Epidemiol 1996;143:1007-17.

[19] Dodge JA, Lewis PA, Stanton M, Wilsher J. Cystic fibrosis mortality and survival in the UK: 1947-2003. Eur Respir J 2007;29:522-6.

[20] FitzSimmons SC. The changing epidemiology of cystic fibrosis. J Pediatr 1993;122:1-9.

[21] Bossi A, Battistini F, Braggion C, Magno EC, Cosimi A, de Candussio G, et al. Italian cystic fibrosis registry: 10 years of activity. Epidemiol Prev n.d. 1999;23:5-16.

[22] Verma N, Bush A, Buchdahl R. Is there still a gender gap in cystic fibrosis? Chest 2005:128:2824-34.

[23] Viviani L, Bossi A, Assael BM. Absence of a gender gap in survival. an analysis of the Italian registry for cystic fibrosis in the paediatric age. J Cyst Fibros 2011:10:313-7.

[24] Kulich M, Rosenfeld M, Goss CH, Wilmott R. Improved survival among young patients with cystic fibrosis. J Pediatr 2003;142:631-6.

[25] Jackson AD, Daly L, Jackson AL, Kelleher C, Marshall BC, Quinton HB, et al. Validation and use of a parametric model for projecting cystic fibrosis survivorship beyond observed data: a birth cohort analysis. Thorax 2011;66:674-9. 
[26] Bastarache JA, Ong T, Matthay MA, Ware LB. Alveolar fluid clearance is faster in women with acute lung injury compared to men. J Crit Care 2011;26:249-56.

[27] Laube M, Küppers E, Thome UH. Modulation of sodium transport in alveolar epithelial cells by estradiol and progesterone. Pediatr Res 2011;69:200-5.

[28] Trotter A, Ebsen M, Kiossis E, Meggle S, Kueppers E, Beyer C, et al. Prenata estrogen and progesterone deprivation impairs alveolar formation and fluid clearance in newborn piglets. Pediatr Res 2006;60:60-4.

[29] Sweezey N, Tchepichev S, Gagnon S, Fertuck K, O'Brodovich H. Female gender hormones regulate mRNA levels and function of the rat lung epithelial $\mathrm{Na}$ channel. Am J Physiol 1998;274:C379-86.

[30] Sweezey NB, Smith D, Corey M, Ellis L, Carpenter S, Tullis DE, et al. Amilorideinsensitive nasal potential difference varies with the menstrual cycle in cystic fibrosis. Pediatr Pulmonol 2007;42:519-24.

[31] Fanelli T, Cardone RA, Favia M, Guerra L, Zaccolo M, Monterisi S, et al. Betaoestradiol rescues DeltaF508CFTR functional expression in human cystic fibrosis airway CFBE41o-cells through the up-regulation of NHERF1. Biol Cell 2008; 100:399-412.

[32] Coakley RD, Sun H, Clunes LA, Rasmussen JE, Stackhouse JR, Okada SF, et al. 17Beta-estradiol inhibits $\mathrm{Ca}^{2+}$-dependent homeostasis of airway surface liquid volume in human cystic fibrosis airway epithelia. J Clin Invest 2008; $118: 4025-35$

[33] Sheridan JT, Gilmore RC, Watson MJ, Archer CB, Tarran R. 17 $\beta$-Estradiol inhibits phosphorylation of STIM1: implication for store-operated calcium entry and chronic lung diseases. J Biol Chem 2013;288:33509-18.

[34] Saint-Criq V, Kim SH, Katzenellenbogen JA, Harvey BJ. Non-genomic estrogen regulation of ion transport and airway surface liquid dynamics in cystic fibrosis bronchial epithelium. PLoS ONE 2013;8:e78593.

[35] Harrington WR, Kim SH, Funk CC, Madak-Erdogan Z, Schiff R, Katzenellenbogen JA, et al. Estrogen dendrimer conjugates that preferentially activate extranuclear, nongenomic versus genomic pathways of estrogen action. Mol Endocrinol 2006;20:491-502.

[36] Ghisletti S, Meda C, Maggi A, Vegeto E. 17Beta-estradiol inhibits inflammatory gene expression by controlling NF-kappaB intracellular localization. Mol Cell Biol 2005;25:2957-68.

[37] Wang Y, Cela E, Gagnon S, Sweezey NB. Estrogen aggravates inflammation in Pseudomonas aeruginosa pneumonia in cystic fibrosis mice. Respir Res 2010;11:166.

[38] Taggart CC, Cryan S-A, Weldon S, Gibbons A, Greene CM, Kelly E, et al. Secretory leucoprotease inhibitor binds to NF-kappaB binding sites in monocytes and inhibits p65 binding. J Exp Med 2005;202:1659-68.
[39] Chotirmall SH, Greene CM, Oglesby IK, Thomas W, O'Neill SJ, Harvey BJ, et al. 17Beta-estradiol inhibits IL-8 in cystic fibrosis by up-regulating secretory leucoprotease inhibitor. Am J Respir Crit Care Med 2010;182:62-72.

[40] Chotirmall SH, Smith SG, Gunaratnam C, Cosgrove S, Dimitrov BD, O'Neill SJ, et al. Effect of estrogen on pseudomonas mucoidy and exacerbations in cystic fibrosis. N Engl J Med 2012;366:1978-86.

[41] Raoust E, Balloy V, Garcia-Verdugo I, Touqui L, Ramphal R, Chignard M Pseudomonas aeruginosa LPS or flagellin are sufficient to activate TLRdependent signaling in murine alveolar macrophages and airway epithelial cells. PLOS ONE 2009;4:e7259.

[42] Chen CI-U, Schaller-Bals S, Paul KP, Wahn U, Bals R. Beta-defensins and LL-37 in bronchoalveolar lavage fluid of patients with cystic fibrosis. J Cyst Fibros 2004;3:45-50.

[43] Li H, Tu Z, An L, Qian Z, Achilefu S, Gu Y. Inhibitory effects of ER $\beta$ on proliferation, invasion, and tumor formation of MCF-7 breast cancer cells prognostication for the use of ERß-selective therapy. Pharm Biol 2012;50:839-49.

[44] Zhu J, Lu X, Hua K-Q, Sun H, Yu Y-H, Feng Y-J. Oestrogen receptor $\alpha$ mediates $17 \beta$-estradiol enhancement of ovarian cancer cell motility through upregulation of survivin expression. Arch Gynecol Obstet 2012;286:729-37.

[45] Wang SB, Hu KM, Seamon KJ, Mani V, Chen Y, Gronert K. Estrogen negatively regulates epithelial wound healing and protective lipid mediator circuits in the cornea. FASEB J 2012;26:1506-16.

[46] Buchanan PJ, McNally P, Harvey BJ, Urbach V. Lipoxin $A_{4}$-mediated KATP potassium channel activation results in cystic fibrosis airway epithelial repair. Am J Physiol Lung Cell Mol Physiol 2013;305:L193-201.

[47] Fahey JV, Wright JA, Shen L, Smith JM, Ghosh M, Rossoll RM, et al. Estradiol selectively regulates innate immune function by polarized human uterine epithelial cells in culture. Mucosal Immunol 2008;1:317-25.

[48] Pashuck TD, Franz SE, Altman MK, Wasserfall CH, Atkinson MA, Wronski T], et al. Murine model for cystic fibrosis bone disease demonstrates osteopenia and sex-related differences in bone formation. Pediatr Res 2009;65:311-6.

49] Moran A, Dunitz J, Nathan B, Saeed A, Holme B, Thomas W. Cystic fibrosisrelated diabetes: current trends in prevalence, incidence, and mortality Diabetes Care 2009;32:1626-31

[50] Marshall BC, Butler SM, Stoddard M, Moran AM, Liou TG, Morgan WJ Epidemiology of cystic fibrosis-related diabetes. J Pediatr 2005;146:681-7.

[51] Milla CE, Billings J, Moran A. Diabetes is associated with dramatically decreased survival in female but not male subjects with cystic fibrosis. Diabetes Care 2005;28:2141-4. 